\title{
F41 Antigen as a Virulence Factor in the Infant Mouse Model of Escherichia coli Diarrhoea
}

\author{
By ANNE BERTIN \\ INRA, Station de Pathologie de la Reproduction, 37380 Nouzilly, France
}

(Received 22 February 1985 ; revised 4 June 1985)

\begin{abstract}
The properties responsible for the virulence in infant mice of the bovine enterotoxigenic Escherichia coli strain B41 were investigated. A B41 K99- variant previously found to be nearly as virulent as the original strain $\mathrm{B} 41\left(\mathrm{~B} 41 \mathrm{~K}^{\circ} 9^{+}\right)$possessed $\mathrm{F} 41$ antigen and haemagglutinating properties. Two variants that did not haemagglutinate sheep and human erythrocytes were isolated from strain $\mathrm{B} 41 \mathrm{~K} 99^{-}$. These variants simultaneously lost their ability to agglutinate with F41 antiserum and their haemagglutinating properties. They still produced heat-stable enterotoxin. The first B41 K $99^{-} \mathrm{F} 41^{-}$variant was much less virulent than strains B41 K99+ and B41 K99-, the second was not virulent at all. F41 properties were not acquired by other $E$. coli strains by plasmid transfers. Non-haemagglutinating variants could not be obtained from the original strain $\mathrm{B} 41 \mathrm{~K} 99^{+}$. However, a $\mathrm{B} 41 \mathrm{~K} 99^{+} \mathrm{F} 41^{-}$strain was obtained by a four-step procedure: (i) spontaneous loss of the $\mathrm{K} 99$ plasmid, (ii) obtaining a nalidixic acid-resistant mutant, (iii) obtaining a non-haemagglutinating F41- variant, (iv) reacquisition of the K99 plasmid. This $\mathrm{B} 41 \mathrm{Nal}^{\mathrm{r}} \mathrm{K} 99^{+} \mathrm{F} 41^{-}$strain, although producing heat-stable toxin, was not at all virulent, whereas reacquisition of the $\mathrm{K} 99$ plasmid by the strain $\mathrm{B} 41 \mathrm{Nal}^{\mathrm{r}} \mathrm{F} 41^{+}$restored virulence. These results show that F41 antigen is an important virulence factor of strain B41 in the infant mouse model.
\end{abstract}

\section{INTRODUCTION}

Virulence factors have been identified in enterotoxigenic Escherichia coli (ETEC), including components responsible for adherence of bacteria to the intestinal epithelium, and toxins (Gaastra \& De Graaf, 1982; Gyles et al., 1974; Smith \& Halls, 1967; Smith \& Linggood, 1971, 1972). The ETEC adherence factors include plasmid-determined pili, antigenic structures, such as K88 found in ETEC isolated from piglets (Jones \& Rutter, 1972; Stirm et al., 1967), K99 antigen found in ETEC strains isolated from calves, lambs and piglets (Ørskov et al., 1975) and CFA/I and CFA/II antigens found in E. coli isolated from humans (Evans et al., 1975; Evans \& Evans, 1978). Recently, however, other surface structures, both pilus-like and non pilus-like, and assumed to have the same role, have been at least partly characterized (Awad-Masalmeh $e t$ al., 1982; Gaastra \& De Graaf, 1982). Furthermore, some adhesins are more complex than at first realized. For example, ETEC strains possessing CFA/II antigen have been found to possess two antigens of three antigenic types $\left(\mathrm{CS}_{1}+\mathrm{CS}_{3}\right)$ or $\left(\mathrm{CS}_{2}+\mathrm{CS}_{3}\right)$ with different haemagglutinating properties (Cravioto et al., 1982; Mullany et al., 1983; Smyth, 1982). Also strain B41, which produces K99 antigen, produces another antigenic and haemagglutinating surface structure, not expressed at $18^{\circ} \mathrm{C}$, which causes adherence to intestinal cells (De Graaf \& Roorda, 1982; Morris et al., 1978, 1980, 1982). This antigen, called F41 (De Graaf \& Roorda, 1982; Morris et al., 1982), is believed to be a pilus-like structure (De Graaf \& Roorda, 1982) and a variant strain, $\mathrm{B} 41 \mathrm{~K} 99^{-} \mathrm{F} 41^{+}$, was still able to produce diarrhoea in gnotobiotic piglets (Morris et al., 1982).

Abbreviations: ETEC, enterotoxigenic $E$. coli; ST toxin, heat-stable enterotoxin. 
An infant mouse model of $E$. coli diarrhoea was established by Duchet-Suchaux (1980). In this model the oral inoculation of infant mice with strain B41 provokes rapid death (DuchetSuchaux, 1980). A B41 variant which does not produce K99 antigen is still fully virulent, while $E$. coli strains having acquired the ability to produce K99 antigen and heat-stable enterotoxin (ST toxin) by plasmid transfer are much less virulent than strains B41 and B41 K99-, or not virulent at all (Bertin, 1983). These results suggested that another property (or properties) of the B41 K99- strain, absent from the transconjugant clones, was (were) responsible for the virulence of strain B41 for the infant mouse and that F41 antigen was a good candidate for this role (Bertin, 1983).

This report describes further study of the virulence of strain B41 for the infant mouse with particular consideration of the role of F4l antigen.

\section{METHODS}

Bacterial strains. Escherichia coli strain B41 is a bovine reference strain (Smith, 1971) provided by Ph. Gouet, INRA, Theix, France. Strain B41* is supposedly the same strain but was provided by P. Pohl, Institut National de Recherches Veterinaires, Groeselenberg, Bruxelles, Belgium. This strain originated from I. Ørskov. Strain B41A is a B41 K99- variant obtained in this laboratory that still has the ability to produce the ST toxin (Bertin, 1983). Strains C600(1), H510(1), 3404(1) and K14(1) are E. coli K12 and non-ETEC E. coli reference strains of serotypes O101, 08 and $\mathrm{O} 9$ which have acquired by plasmid transfer from strain B41 (selection for tetracycline resistance) a plasmid coding for tetracycline ( $\mathrm{Tc}$ ), streptomycin $(\mathrm{Sm})$ and sulphonamide ( $\mathrm{Su}$ ) resistances (Bertin, 1983). Strains $\mathrm{C600(2),} \mathrm{H} 510(2), 3404(2)$ and $\mathrm{K} 14(2)$ have additionally acquired from strain B41 a plasmid coding for K99 antigen and ST toxin (Bertin, 1983). The main characteristics of all these strains are listed in Table 2.

The strain used for plasmid mobilization was 28R315 (J53-R1-19drd) originating from Dr M. M. McConnell, Central Public Health Laboratory, London, UK. Reference plasmids were R702 (46 MDal), RI (62 MDal), RA1-1 (85 MDal), Rts1 (120 MDal) provided by C. Waalwijk, Vrije University, Amsterdam, Holland, V517 (Macrina et al., 1978) and C600R P4 (Datta et al., 1971).

Production of antiserum. Antisera were produced in rabbits by multiple intravenous injections of bacteria (live or formalin-treated) that had been grown at $37^{\circ} \mathrm{C}$ on minca agar (Guinée et al., 1977). Specific anti-K99 serum was prepared by absorbing $\mathrm{B} 41$ antiserum with the $\mathrm{B} 41 \mathrm{~K}^{2} 9^{-}$variant grown at $37^{\circ} \mathrm{C}$ on minca agar. $\mathrm{F} 41$ antiserum was prepared against the $\mathrm{B} 41 \mathrm{~K} 99^{-}$variant and was absorbed by the same strain cultivated at $18^{\circ} \mathrm{C}$ on minca agar.

Haemagglutination tests. These were done by slide agglutination at room temperature. One drop of a dense suspension of bacteria grown for $18-24 \mathrm{~h}$ at $37^{\circ} \mathrm{C}$ on minca medium was added to one drop of washed erythrocytes diluted 1/5 in Mayer veronal buffer (Mayer et al., 1948) containing 0.5\% (w/v) mannose. Immediate and strong agglutination was recorded as ++ , and slower agglutination appearing in less than $5 \mathrm{~min}$ was recorded as + .

Determination of other characteristics of the strains. Biochemical metabolic profiles were determined by the API system, and resistance to antibiotics by using disks (Bio-Mérieux) on Mueller-Hinton agar. ST toxin production was determined by the suckling mouse assay (Dean et al., 1972) by oral inoculation (Stavric \& Jeffrey, 1977).

Selection of nonhaemagglutinating ( $M R H A^{-}$) variants. A haemadsorption method derived from that of Sedlock $e t$ al. (1982) was used. Broth cultures of strains B41 or B41 A were diluted and plated on minca agar so as to obtain about 100 isolated colonies. The plates were incubated for $48 \mathrm{~h}$ at $37^{\circ} \mathrm{C}$ and cooled to $4{ }^{\circ} \mathrm{C}$ just before testing. A volume $(5 \mathrm{ml})$ of a $10 \%(\mathrm{v} / \mathrm{v})$ suspension of washed sheep erythrocytes in Mayer veronal buffer containing $0.5 \%$ (w/v) mannose was poured slowly onto each plate and rocked gently for about $2 \mathrm{~min}$. The erythrocyte suspension was then aspirated. Colonies that appeared not to adsorb erythrocytes were sampled for cloning and further characterization.

Plasmid analysis. The plasmid content of the strains was analysed by agarose gel electrophoresis after alkaline extraction by the method of Kado \& Liu (1981). Electrophoresis was done in a vertical apparatus (gel dimensions $16 \times 14 \times 3 \mathrm{~mm})$ with ten sample slots $(15 \times 8 \times 3 \mathrm{~mm})$. Gels $(0.8 \%$, w/v, agarose; Sigma type II, medium EEO) were electrophoresed for $150 \mathrm{~min}$ at $120 \mathrm{~V}$, stained for $20 \mathrm{~min}$ with ethidium bromide $\left(0.4 \mu \mathrm{g} \mathrm{ml}^{-1}\right)$ and photographed under UV light (short-wave transillumination type C61) onto Polaroid type 665 film with a yellow filter. The molecular weights of the plasmids were estimated by calculation from a linear regression curve obtained from mobility of standard plasmids.

Selection of nalidixic acid resistant ( Nalr) mutants. Spontaneous $\mathrm{Nal}^{\mathrm{r}}$ mutants (resistant to $50 \mu \mathrm{g} \mathrm{ml}^{-1}$ ) were isolated on trypticase soy agar (TSA) (Bio-Mérieux) plates containing increasing concentrations of nalidixic acid. $\mathrm{Nal}^{\mathrm{r}}$ clones were chosen from those having the same size and appearance as the original strain on TSA.

Plasmid transfers. Donor, recipient and mobilizing strains were each cultured in $10 \mathrm{ml}$ trypticase soy broth for $18-24 \mathrm{~h}$ at $37^{\circ} \mathrm{C}$. Then $0.02 \mathrm{ml}$ of each culture was added to $10 \mathrm{ml}$ trypticase soy broth and cultivated for a further $18-24 \mathrm{~h}$ at $37^{\circ} \mathrm{C}$. Selection of transconjugants was made on TSA with tetracycline $\left(16 \mu \mathrm{g} \mathrm{ml}^{-1}\right)$ and nalidixic acid $\left(40 \mu \mathrm{g} \mathrm{m}^{-1}\right)$. 
Table 1. Mannose-resistant haemagglutinating properties of strains of E. coli and their reaction with the anti-F41 serum

Haemagglutination of erythrocyte types:

\begin{tabular}{|c|c|c|c|c|c|c|}
\hline \multirow[b]{2}{*}{ Strain $†$} & & \multirow{2}{*}{$\begin{array}{l}\text { Agglutination } \\
\text { with anti-F41 }\end{array}$} \\
\hline & Human A & Bovine & Horse & Sheep & Guinea-pig & \\
\hline $\mathrm{B} 41, \mathrm{~B} 41^{*}$ and $\mathrm{B} 41 \mathrm{~A}$ & ++ & + & ++ & ++ & ++ & + \\
\hline $\mathrm{C} 600(1), \mathrm{H} 510(1), 3404(1)$ and $\mathrm{K} 14(1)$ & - & - & - & - & - & - \\
\hline $\mathrm{C} 600(2), \mathrm{H} 510(2), 3404(2)$ and $\mathrm{K} 14(2)$ & - & + & ++ & - & - & - \\
\hline$B 41 B_{1}$ and $B 41 B_{2}$ & - & + & + & - & + & - \\
\hline $\mathrm{B} 41^{*} \mathrm{C}$ & ++ & + & + & ++ & ++ & + \\
\hline $\mathrm{B} 41^{*} \mathrm{CB}$ & - & + & - & - & + & - \\
\hline
\end{tabular}

† See text and Table 2 for details.

Pathogenicity for infant mice. Infant OFl mice (IFFA-Credo, L'Arbresle, France) born from at least nine animals for each experiment were randomly redistributed (eight per mother) $18 \mathrm{~h}$ before inoculation. At inoculation they were $18-48 \mathrm{~h}$ old and weighed about $2 \mathrm{~g}$. Each experiment was done using three mothers $(=24$ infant mice). For inoculation, bacteria were grown on TSA slants for $18-24 \mathrm{~h}$ at $37^{\circ} \mathrm{C}$, and suspended in saline $\left(9 \mathrm{~g} \mathrm{NaCl}^{-1}\right)$. Infant mice were inoculated orally with $10^{3}$ or $10^{5}$ bacteria by means of a calibrated platinum loop. Mortality was recorded each day for $6 \mathrm{~d}$.

\section{RESULTS}

Strain B41K99- (B41 A) did not agglutinate with a K12K99 antiserum, and when cultivated at $37^{\circ} \mathrm{C}$ did not absorb K99 antibodies (Bertin, 1983). A serum (referred to as anti-F41 serum) against this $\mathrm{B} 41 \mathrm{~K} 99^{-}$variant absorbed with the same strain cultivated at $18^{\circ} \mathrm{C}$ was obtained. This serum agglutinated the $\mathrm{B} 41 \mathrm{~K} 99^{-}$variant cultivated at $37^{\circ} \mathrm{C}$, giving evidence in this strain of at least one antigenic structure not expressed at $18^{\circ} \mathrm{C}$ (Table 1). This is a characteristic reported for F41 antigen (De Graaf \& Roorda, 1982; Morris et al., 1982). Like the original B41 strain, the B41 K99- variant, when grown at $37^{\circ} \mathrm{C}$ on minca medium, induced immediate mannose-resistant haemagglutination of human group $\mathrm{A}$, horse, sheep and guinea-pig erythrocytes at room temperature while bovine erythrocytes reacted more slowly (Table 1). Mannose-resistant haemagglutinating properties have also been reported associated with the presence of F41 antigen (De Graaf \& Roorda, 1982; Morris et al., 1982).

Non-ETEC E. coli strains having acquired only antibiotic resistances by plasmid transfer from strain B41 did not acquire haemagglutinating properties (Table 1). The same strains which had in addition acquired the ability to produce K99 antigen and ST toxin also acquired the ability to haemagglutinate horse erythrocytes immediately and bovine erythrocytes more slowly (Table 1). None of these strains agglutinated with the anti-F41 serum (Table 1).

\section{Isolation of non-haemagglutinating $\left(\mathrm{MRHA}^{-}\right) \mathrm{FHI}^{-}$variants from strain $\mathrm{B} 4 \mathrm{AA}$}

Two colonies which did not appear to adsorb sheep erythrocytes on agar plates were cloned twice and characterized. They had the same metabolic profile, antibiotic resistance $\left(\mathrm{Sm}^{\mathrm{r}} \mathbf{T c}^{\mathrm{r}} \mathrm{Su}^{\mathrm{r}}\right)$ and apparent plasmid profile as strains B41 and B41A (Fig. 1). These clones, called B41 B And $_{1}$ $B 41 B_{2}$, had totally lost the ability to haemagglutinate human and sheep erythrocytes, and haemagglutination of guinea pig and horse erythrocytes appeared more slowly than with the original strain (Table 1). Clones $\mathrm{B}_{41} \mathrm{~B}_{1}$ and $\mathrm{B} 41 \mathrm{~B}_{2}$ had also lost the ability to be agglutinated by the anti-F41 serum (Table 1).

\section{Obtaining B4INalr $\mathrm{K99}^{+} \mathrm{MRHA}^{+}\left(\mathrm{F4I}^{+}\right)$and $\mathrm{B} 41 \mathrm{Nal} \mathrm{K}^{2} 9^{+} \mathrm{MRHA}^{-}\left(\mathrm{FHI}^{-}\right)$strains}

It proved impossible to isolate non-haemagglutinating variants from strain B41, perhaps because K99 antigen might have masked, at least in part, the F41 structure. Surprisingly, strain B41 from another source (called B41*; see Methods) was found to contain only one large plasmid of about $90 \mathrm{MDal}$ (Fig. 1, lane 7), which was transferable after mobilization to E. coli C600 (Fig. 1, lane 6). Presence of this plasmid was associated with the $\mathrm{Sm}^{r} \operatorname{Tc}^{r} \mathrm{Su}^{\mathrm{r}}, \mathrm{K} 99$ and $\mathrm{ST}$ 


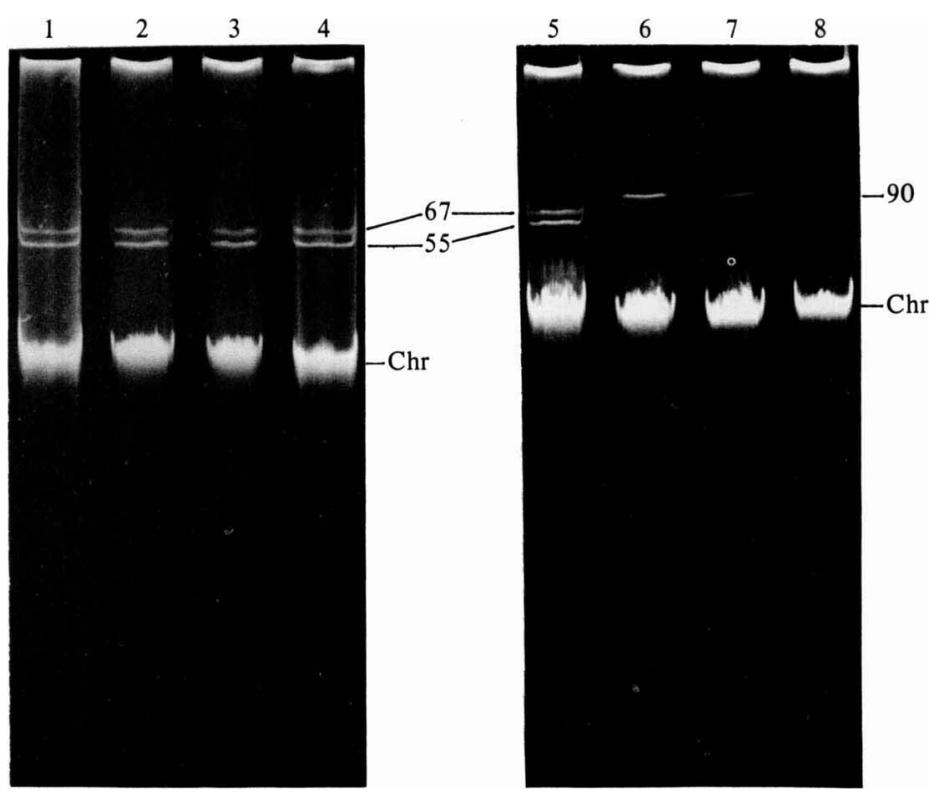

Fig. 1. Plasmid content of various $E$. coli strains. Agarose gel electrophoresis $(0.8 \%, \mathrm{w} / \mathrm{v})$ was done after alkaline extraction by the method of Kado \& Liu (1981) as described in Methods. Lanes 1 and 5, strain

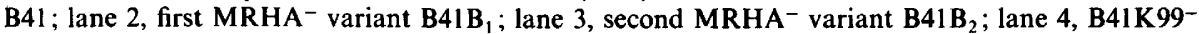
variant (strain B41 A); lane 6, transconjugant C600 clone $\left(\mathrm{B} 41^{*} \times \mathrm{C} 600\right) \mathrm{Sm}^{r} \mathrm{Tc}^{r} \mathrm{Su}^{r} \mathrm{~K}^{2} 9^{+} \mathrm{ST}^{+}$; lane 7 , strain $\mathrm{B} 41^{*}$; lane 8 , strain $\mathrm{B} 41^{*} \mathrm{C}\left(\mathrm{Sm}^{\mathrm{s}} \mathrm{Tc}^{\mathrm{s}} \mathrm{Su}^{\mathrm{s}} \mathrm{K} 99^{-} \mathrm{ST}-\right.$ derivative of $\left.\mathrm{B} 41^{*}\right)$. The sizes (MDal) of the plasmids are indicated. Chr, chromosonal DNA.

characteristics. The sizes of the two large plasmids of strain B41 were estimated as about $67 \mathrm{MDal}$ and $55 \mathrm{MDal}$ under the same conditions (Fig. 1). In addition to these plasmids, two plasmid DNA bands migrating ahead of the chromosome were seen after alkaline extraction (Fig. 1). One or the other was sometimes cotransferred without the appearance of detectable phenotypic characteristics.

Forty-one clones of strain B41* were taken from the medium of Bochner et al. (1980) for positive selection for loss of tetracycline resistance, and characterized. Of these, 35 had lost tetracycline resistance only, two had lost tetracycline resistance and ST toxin, and one had lost the resistances to tetracycline, streptomycin and sulphonamides as well as K99 antigen and ST toxin production. This last clone, $\mathrm{B} 41^{*} \mathrm{C}$, had lost the $90 \mathrm{MDal}$ plasmid (Fig. 1, lane 8). It was still able to produce $\mathrm{F} 41$ antigen and haemagglutinated horse erythrocytes more slowly than the original strain $\mathrm{B} 41^{*}$ (Table 1). From clone $\mathrm{B} 41^{*} \mathrm{C}$, a Nal mutant was obtained, and from this mutant, a sheep erythrocyte non-haemagglutinating variant, B41*CB. This last clone had the same haemagglutinating properties with sheep and human erythrocytes as the other sheep erythrocyte non-haemagglutinating strains and did not agglutinate with anti-F4l serum (Table 1). The $90 \mathrm{MDal} \mathrm{B} 41^{*}$ plasmid was transferred by mobilization into these two Nalr strains, restoring the $\mathrm{B} 41^{*}$ phenotype in the former (strain $\mathrm{B} 41^{*} \mathrm{CD}$ ) and giving a $\mathrm{B} 41^{*} \mathrm{Nal}^{\mathrm{r}} \mathrm{K} 99^{+}$ $\mathrm{MRHA}^{-}\left(\mathrm{F} 41^{-}\right) \mathrm{ST}^{+}$variant in the latter (strain B41*DB).

The main characteristics of all these strains are listed in Table 2.

\section{Virulence of strains for infant mice}

It has been established that infant mice less than $48 \mathrm{~h}$ old are very sensitive to $\mathrm{K} 99^{+} \mathrm{ST}^{+}$ ETEC strains such as strain B41 when orally inoculated; death of the animals is associated with intestinal fluid accumulation, diarrhoea and abnormal proliferation of the inoculated strain in the intestine (Duchet-Suchaux, 1980). Doses as small as 10 bacteria kill $40-60 \%$ of the animals in less than $6 \mathrm{~d}$, and inoculation with $10^{3}$ bacteria regularly kills $80-100 \%$ of the animals. The 
Table 2. Main characteristics of the strains

\begin{tabular}{|c|c|c|c|c|c|c|c|}
\hline \multirow[b]{2}{*}{ Strain $\dagger$} & \multicolumn{4}{|c|}{$\begin{array}{l}\text { Characteristics associated } \\
\text { or supposedly associated } \\
\text { with pathogenicity }\end{array}$} & \multicolumn{3}{|c|}{ Presence of plasmid(s) coding for: } \\
\hline & $\begin{array}{c}\text { K99 } \\
\text { antigen }\end{array}$ & $\begin{array}{c}\text { F41 } \\
\text { antigen }\end{array}$ & $\begin{array}{l}\mathrm{ST} \\
\text { toxin }\end{array}$ & MRHA & $\begin{array}{l}\text { K99-ST } \\
(67 \text { MDal })\end{array}$ & $\begin{array}{l}\mathrm{Sm}^{r} \mathrm{Tc}^{r} \mathrm{Su}^{r} \S \\
\text { (55 MDal) }\end{array}$ & $\begin{array}{c}\text { K99-ST Smr Tcr } \mathrm{Su}^{r} \S \\
\text { (90 MDal) }\end{array}$ \\
\hline B41 & + & + & + & + & + & + & - \\
\hline $\mathrm{B} 41 \mathrm{~A}^{a}$ & - & + & + & + & + & + & - \\
\hline $\begin{array}{c}\mathrm{C} 600(1), \mathrm{H} 510(1), \\
\mathrm{H} 510(1), 3404(1) \\
\text { and } \mathrm{K} 14(1)^{b}\end{array}$ & - & - & - & - & - & + & - \\
\hline $\begin{array}{l}\mathrm{C} 600(2), \mathrm{H} 510(2) \\
3404(2) \text { and } \\
\mathrm{K} 14(2)^{\mathrm{c}}\end{array}$ & + & - & + & - & + & + & - \\
\hline $\mathrm{B} 41 \mathbf{B}_{1}$ and $\mathrm{B} 41 \mathbf{B}_{2}^{d}$ & - & - & + & - & + & + & - \\
\hline $\mathrm{B} 41^{* e}$ & + & + & + & + & - & - & + \\
\hline $\mathrm{B} 41^{*} \mathrm{C} f$ & - & + & - & + & - & - & - \\
\hline $\mathrm{B} 41^{*} \mathrm{CD}^{g}$ & + & + & + & + & - & - & + \\
\hline $\mathrm{B} 41^{*} \mathrm{CB}^{h}$ & - & - & - & - & - & - & - \\
\hline $\mathrm{B} 41^{*} \mathrm{DB}^{i}$ & + & - & + & - & - & - & + \\
\hline
\end{tabular}

$\dagger a$, Variant of strain B41 which does not produce K99 antigen but still has the other characteristics of strain B41; $b$, non-ETEC transconjugants which have acquired the $\mathrm{Sm}^{r} \mathrm{Tc}^{r} \mathrm{Su}^{r}$ (55 MDal) plasmid from strain B41; , non-ETEC transconjugants which have acquired the $\mathrm{Sm}^{r} \mathrm{Tc}^{r} \mathrm{Su}^{r}(55 \mathrm{MDal})$ and K99-ST (67 MDal) plasmids from strain $\mathrm{B} 41 ; d$, variants isolated from strain B41 A as non-haemagglutinating clones and not agglutinating with $\mathrm{F} 4 \mathrm{I}$ antiserum; $e$, this reference strain B41 (different source from B41: see Methods) possesses only a single large plasmid (90 MDal) coding for K99-ST and $\mathrm{Sm}^{r} \mathrm{Tc}^{r} \mathrm{Su}^{r} ; f$, strain B41* having lost the $90 \mathrm{MDal}$ plasmid; $g, \mathrm{Nal}$ mutant of strain $\mathrm{B} 41^{*} \mathrm{C}$ which has reacquired the $90 \mathrm{MDal}$ plasmid; $h$, variant of a $\mathrm{Nal}^{r}$ mutant of strain $\mathrm{B} 41^{*} \mathrm{C}$, isolated as a non-haemagglutinating clone and does not agglutinate with $\mathrm{F} 41$ antiserum; $i$, strain $\mathrm{B} 41^{*} \mathrm{CB}$ which has reacquired the $90 \mathrm{MDal}$ plasmid.

$\uparrow$ Mannose-resistant haemagglutination with sheep erythrocytes.

$\S$ Each strain possessing this plasmid is resistant to streptomycin, tetracycline and sulphonamide.

Table 3. Virulence of E. coli strains assessed in the infant mouse model

\begin{tabular}{|c|c|c|c|}
\hline \multirow[b]{2}{*}{ Strain } & & \multicolumn{2}{|c|}{$\begin{array}{l}\text { Mortality } \dagger 5 \mathrm{~d} \\
\text { after inoculation with: }\end{array}$} \\
\hline & & $10^{3}$ bacteria & $10^{5}$ bacteria \\
\hline B41 & & $23 / 24$ & $24 / 24$ \\
\hline B41* & & $22 / 24$ & $24 / 24$ \\
\hline B41A & & $23 / 24$ & $24 / 24$ \\
\hline \multirow{2}{*}{$\mathrm{B} 4 \mid \mathrm{B}_{1}$} & Expt 1 & $0 / 24$ & $0 / 24$ \\
\hline & Expt 2 & $0 / 24$ & $0 / 24$ \\
\hline \multirow[t]{2}{*}{$\mathrm{B} 41 \mathrm{~B}_{2}$} & Expt 1 & $6 / 24$ & $9 / 24$ \\
\hline & Expt 2 & $10 / 24$ & $10 / 24$ \\
\hline \multirow[t]{2}{*}{$\mathrm{B} 41^{*} \mathrm{CD}$} & Clone I & $15 / 24$ & $24 / 24$ \\
\hline & Clone 2 & $23 / 24$ & $24 / 24$ \\
\hline \multirow[t]{2}{*}{$\mathrm{B} 41^{*} \mathrm{DB}$} & Clone 1 & $0 / 24$ & $0 / 24$ \\
\hline & Clone 2 & $1 / 24$ & $0 / 24$ \\
\hline
\end{tabular}

† No. of infant mice dead/no. of infant mice inoculated.

susceptibility of the mice decreases with age, and after $10 \mathrm{~d}$ they are no longer susceptible (Duchet-Suchaux, 1980). In the present study standard inocula of $10^{3}$ (or, for less pathogenic strains, $10^{5}$ ) bacteria were used.

Non-ETEC E. coli strains C600, H510, K14 and 3404 which had acquired the K99-ST plasmid by matings from strain B41 killed, respectively, $0 / 24,1 / 23,10 / 48$ and $0 / 24$ of the animals after inoculation with $10^{5}$ bacteria. These strains were thus much less virulent than strain B41 (Bertin, 1983). The B41K99- variant strain B4l A was still very virulent: the same final rate of death as the original strain $\mathrm{B} 41 \mathrm{~K} 99^{+}$was obtained (Table 3 ), but death was delayed by about 24 h (Bertin, 1983). 


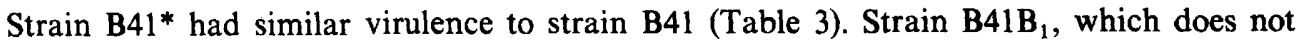
produce $\mathrm{F} 41$ antigen, was not virulent at all, whereas the second $\mathrm{F} 41^{-}$variant $\left(\mathrm{B} 41 \mathrm{~B}_{2}\right)$ did show some virulence (Table 3 ).

Strains that did not produce ST toxin were not virulent at all. Virulence was restored when the $\mathrm{Nal}^{\mathrm{r}}$ mutant of strain $\mathrm{B} 41^{*} \mathrm{C}$ reacquired the K99-ST Sm${ }^{\mathrm{r}} \mathrm{Tc}^{\mathrm{r}} \mathrm{Su}^{\mathrm{r}} 90 \mathrm{MDal}$ plasmid (strain $\mathrm{B} 41^{*} \mathrm{CD}$ ) (two transconjugant clones tested, Table 3 ). The $\mathrm{F}^{-} 1^{-}$variant of the same strain which had acquired the same plasmid and phenotypic characteristics (strain B41*DB) was not virulent at all (two transconjugant clones tested, Table 3).

\section{DISCUSSION}

F41 antigen has been found in the bovine reference ETEC strain B41 (De Graaf \& Roorda, 1982; Morris et al., 1983). It mediates bacterial adherence to intestinal epithelial cells (Morris et al., 1983), but its exact role in pathogenicity is not known. In this report, a genetic approach to the problem, especially by obtaining $\mathrm{F}^{-} 1^{-}$variants, has shown that the F41 antigen is an important virulence factor in an infant mouse model.

In this model of $E$. coli diarrhoea a B41K99- variant (strain B41A) was nearly as pathogenic as the original strain $\mathrm{B} 41$, and transconjugant $\mathrm{K}^{+} 9^{+} \mathrm{ST}^{+} E$. coli clones were much less virulent or not virulent at all (Bertin, 1983). The B41K99- variant strain B41A, but not the $E$. coli strains having acquired by plasmid transfer K99 and ST characteristics or other plasmids from strain B41, had properties reported to be F41-associated, namely agglutination with a serum against antigens of strain B41 different from $\mathrm{K} 99$ antigen and also not expressed at $18^{\circ} \mathrm{C}$ on minca medium, and mannose-resistant haemagglutinating properties (De Graaf \& Roorda, 1982; Morris et al., 1982).

F41 antigen was found by titration assay at $4{ }^{\circ} \mathrm{C}$ in the presence of mannose to haemagglutinate strongly human group A erythrocytes and guinea-pig erythrocytes and, to a lesser extent, sheep and horse erythrocytes (De Graaf \& Roorda, 1982). Also, the haemagglutinating properties of the $\mathrm{F} 41$ antigen were not readily reproducible at low temperatures but at room temperature this structure haemagglutinated sheep, guinea-pig and horse erythrocytes (Ollier \& Girardeau, 1983). The B41 K99- variant strain B41 A also induced mannose-resistant haemagglutination of human A type, horse, sheep and guinea-pig erythrocytes.

Each MRHA- variant isolated had entirely lost the ability to induce rapid haemagglutination at room temperature of human group $A$ and sheep erythrocytes, and haemagglutination of horse and guinea-pig erythrocytes was markedly slowed. At the same time they lost the ability to be agglutinated by a serum against a structure from B41 K99- not expressed at $18^{\circ} \mathrm{C}$ on minca medium. It seems likely that the $\mathrm{MRHA}^{-}$variants have lost entirely, or have very greatly reduced amounts of the F41 antigen. This structure is incompletely characterized and has been provisionally called F41 by De Graaf \& Roorda (1982). The purified material has a filamentous structure and their B41K99- variant (strain B41M) has very thin pili that are not produced at $18^{\circ} \mathrm{C}$ (De Graaf \& Roorda, 1982). However, two mannose-resistant haemagglutinins have also been found in a B41 K99- variant and it is not certain that the B41 anionic adhesin is a fimbrial structure (Chanter, 1983). The full characterization of this structure and its role in pathogenesis has been complicated by the failure to obtain $\mathrm{F} 41^{-}$variants (Morris et al., 1982).

I found that strain B41 from one origin had two large plasmids, the first coding for K99 and ST characteristics and the second for resistances to streptomycin, tetracycline and sulphonamide (Bertin, 1983). Surprisingly, strain B41 from a different origin (strain B41*) had only a single, larger plasmid coding for all these characteristics. This suggests that plasmid recombination can occur, perhaps facilitated by the presence of transposons, since ST toxin is coded by a transposon in this strain (So et al., 1979). Before my first report (Bertin, 1983), production of K99 antigen and ST toxin had not been reported as being coded by the same plasmid in strain B41 (Meyers et al., 1976; So et al., 1976; Van Embden et al., 1980). Strains B41 and B41* had identical phenotypic characteristics and both were virulent for infant mice. 
In agreement with earlier studies (De Graaf \& Roorda, 1982) I did not detect F41 antigen or F41-specific haemagglutinating properties in any of the transconjugant clones. Also the B41* clone which had lost the $90 \mathrm{MDal}$ plasmid possessed $\mathrm{F} 4 \mathrm{l}$-associated properties. All these results suggest that $\mathrm{F} 41$ is not a plasmid-determined characteristic.

Loss of K99 antigen by the strain B41 does not modify its haemagglutinating properties, least of all its horse and bovine haemagglutinating properties. However, these properties were transferred with the $\mathrm{K} 99$ plasmid since $\mathrm{K} 99^{+}$transconjugants of $E$. coli agglutinated horse and bovine erythrocytes. This poses the question of the structural relationships between K99 antigen and haemagglutinins and the possible existence of several haemagglutinins with the same specificity in E. coli B41.

ST toxin is essential for virulence, The B41 $\mathrm{MRHA}^{-}\left(\mathrm{F}^{-} 1^{-}\right)$variants, still producing ST toxin, were much less virulent for infant mice than strains B41 and B41 A or not virulent at all. So far, no difference in phenotypic characteristics has been detected between these variants. The second variant may be able to produce a very small amount of F41 structure, as suggested by electron microscopy (unpublished observations). Mortality was not appreciably increased by increasing the inoculum from $10^{3}$ to $10^{5}$ bacteria. This could reflect a characteristic relevant to the model. The degree of virulence could not be exactly represented as a simple toxic effect. It is probable that for the inoculated bacteria to implant successfully in the intestine they must implant before, or successfully compete with, other micro-organisms. The second step is abnormal proliferation of the bacteria, probably relevant to the death of the animals, and would depend on the characteristics of the bacteria, especially their adherence ability. Perhaps for this second step, inoculated doses are of less importance. I found that the non-pathogenic or poorly pathogenic strains $\mathrm{H} 510(2), \mathrm{K} 14(2)$ and 3404 (2) comprised the dominant enterobacterial population of the intestines of survivors $5 \mathrm{~d}$ after inoculation (Bertin, 1983).

Strain B41*DB, which is $\mathrm{F} 41^{-}$but possesses $\mathrm{K} 99$ antigen and produces $\mathrm{ST}$ toxin is not virulent at all, showing that F41 antigen is indispensable for virulence.

A B41 K99- $\mathrm{F}^{+} 1^{+}$variant produces diarrhoea in gnotobiotic piglets (Morris et al., 1982). F41 antigen has now been found in numerous ETEC strains, in $\mathrm{K}^{9} 9^{+}$strains of serotypes $\mathrm{O} 9$ and O101 (Morris et al., 1980), and also in porcine strains that do not produce K88, K99 and 987P antigens (Morris et al., 1983; To, 1984).

Because ETEC diarrhoea is not easily reproduced in natural hosts, and experiments with a great number of animals are costly, studies have been made in an infant mouse model (Bertin, 1983; Duchet-Suchaux, 1980). Analysis of the B41 virulence factors in this model shows that ST toxin is necessary for virulence but not sufficient alone to render any $\mathrm{ST}^{+} E$. coli virulent. The most important surface structure involved in the virulence of strain B41 appears to be an F41like structure. The validity of the model for other ST-producing E. coli strains is currently being assessed.

I thank the people mentioned in this paper for providing me with E. coli strains, P. Menanteau for her technical assistance in some of the experiments, and E. Rabouan and H. Le Roux for care and maintenance of the experimental animals. I also thank M. Plommet for constant interest.

\section{REFERENCES}

Awad-Masalmeh, M., Moon, H. W., Runnels, P. L. \& SChNeider, R. A. (1982). Pilus production, hemagglutination, and adhesion by porcine strains of enterotoxigenic Escherichia coli lacking K88, K99 and $987 \mathrm{P}$ antigens. Infection and Immunity 35, 305313.

BERTIN, A. (1983). Virulence factors of enterotoxigenic E. coli studied in the infant mouse model. Annales de recherches vétérinaires $14,169-182$.

Bochner, B. R., Huang, H. C., Schieven, G. L. \& AMES, B. N. (1980). Positive selection for loss of tetracycline resistance. Journal of Bacteriology 143, 926-933.
Chanter, N. (1983). Partial purification and characterization of two non-K99 mannose-resistant haemagglutinins of Escherichia coli B41. Journal of General Microbiology 129, 235-243.

Cravioto, A., Scotland, S. M. \& Rowe, B. (1982). Hemagglutination activity and colonization factor antigens I and II in enterotoxigenic strains of Escherichia coli isolated from humans. Infection and Immunity 36, 189-197.

Datta, N., Hedges, R. W., Shaw, E. J., Sykes, R. B. \& Richmond, M. H. (197I). Properties of an R factor from Pseudomonas aeruginosa. Journal of Bacteriology 108, 1244-1249. 
Dean, A. G., Ching, Y. C., Williams, R. G. \& HARDEN, L. B. (1972). Test for Escherichia coli enterotoxin using infant mice. Application in a study of diarrhea in children in Honolulu. Journal of Infectious Diseases 125, 407-411.

De Graaf, F. K. \& Roorda, I. (1982). Production, purification and characterization of the fimbrial adhesive antigen F41 isolated from calf enteropathogenic Escherichia coli strain B41M. Infection and Immunity 36, 751-758.

DUCHET-SuchauX, M. (1980). Le souriceau, modèle d'étude de la diarrhée colibacillaire. Annales de microbiologie 131B, 239-250.

Evans, D. G. \& Evans, D. J. (1978). New surface associated heat labile colonization factor (CFAII) produced by enterotoxigenic Escherichia coli of serogroups $\mathrm{O} 6$ and 08 . Infection and Immunity 21, 637-647.

Evans, D. G., Silver, R. P., Evans, D. J., Chase, D. G. \& GORBACH, S. L. (1975). Plasmid controlled colonization factor associated with virulence in Escherichia coli enterotoxigenic for humans. Infection and Immunity 12, 656-667.

GaAstra, W. \& De GraAf, F. K. (1982). Host specific fimbrial adhesins of non invasive enterotoxigenic Escherichia coli strains. Microbiological Reviews 46, 129-161.

Guinée, P. A. M., VeldKamp, J. \& JanSEN, W. H. (1977). Improved minca medium for the detection of K99 antigen in calf enterotoxigenic strains of Escherichia coli. Infection and Immunity 15, 676-678.

Gyles, C. L., So, M. \& Falkow, S. (1974). The enterotoxin plasmids of Escherichia coli. Journal of Infectious Diseases 130, 40-49.

JoNEs, G. W. \& RUTTER, J. M. (1972). Role of K88 antigen in the pathogenesis of neonatal diarrhea caused by Escherichia coli in piglets. Infection and Immunity 6, 918-927.

KADO, C. I. \& LIU, S. T. (1981). Rapid procedure for detection and isolation of large and small plasmids. Journal of Bacteriology 145, 1365-1373.

MACRINA, F. L., KopeCKo, D. J., Jones, K. R., AYERS, D. J. \& MCCOWEN, S. M. (1978). A multiple plasmid-containing Escherichia coli strain: convenient source of size reference plasmid molecules. Plasmid 1, 417-420.

Mayer, M. M., Croft, C. C. E. \& Gray, M. M. (1948). Kinetic studies on immune hemolysis. Journal of Experimental Medicine 88, 427-444.

Meyers, J. A., Sanchez, D., Elwell, P. \& Falkow, S. (1976). Simple agarose gel electrophoretic method for the identification and characterization of plasmid deoxyribonucleic acid. Journal of Bacteriology 127, 1529-1537.

Morris, J. A., Stevens, A. E. \& SojkA, W. J. (1978). Anionic and cationic components of the K99 surface antigen from Escherichia coli B41. Journal of General Microbiology 107, 173-175.

Morris, J. A., Thorns, C. J. \& SoJKA, W. J. (1980). Evidence for two adhesive antigens on the K99 reference strain Escherichia coli B41. Journal of General Microbiology 118, 107-113.

Morris, J. A., Thorns, C. J., ScotT, A. C., SoJka, W. J. \& WelLs, G. A. (1982). Adhesion in vitro and in vivo associated with an adhesive antigen (F4l) produced by a $\mathrm{K} 99$ mutant of the reference strain
Escherichia coli B41. Infection and Immunity 36, 11461153.

MORRIs, J. A., Thorns, C. J., Wells, G. A. H., ScotT, A. C. \& SoJKA, W. J. (1983). The production of F41 fimbriae by piglet strains of enterotoxigenic Escherichia coli that lack K88, K99 and 987P fimbriae. Journal of General Microbiology 129, 2753-2759.

Mullany, P., Field, A. M., McConnell, M., Scotland, S. M., SMrth, H. R. \& Rowe, B. (1983). Expression of plasmids coding for colonization factor antigen II (CFA/II) and enterotoxin production in Escherichia coli. Journal of General Microbiology 129, 3591-3601.

Ollier, J. L. \& GirardeaU, J. P. (1983). Structures et fonctions hémagglutinantes des pili $\mathrm{K} 99$ dont la biosynthèse est glucose dépendante ou constitutive et des pili F41. Annales de microbiologie 134A, 247-254.

Ørskov, I., Ørskov, F., SMITH, H. W. \& SOJKA, W. J. (1975). The establishment of K99, a thermolabile, transmissible Escherichia coli $\mathrm{K}$ antigen, previously called 'Kco', possessed by calf and lamb enteropathogenic strains. Acta pathologica et microbiologica scandinavica B83, 31-36.

Sedlock, D. M., Bartus, H. F., Zajac, I. \& Actor, P. (1982). Use of a hemadsorption technique to evaluate the stability of the hemagglutination reaction of Escherichia coli cultures possessing human colonization factor antigens. Journal of Clinical Microbiology 15, 554-557.

SMITH, H. W. (1971). The bacteriology of the alimentary tract of domestic animals suffering from Escherichia coli infection. Annals of the New York Academy of Sciences 176, 110-125.

SMITH, H. W. \& HaLls, S. (1967). The transmissible nature of the genetic factor in Escherichia coli that controls enterotoxin production. Journal of General Microbiology 47, 153-161.

Smith, H. W. \& LingGood, M. A. (1971). The transmissible nature of enterotoxin production in a human enteropathogenic strain of Escherichia coli. Journal of Medical Microbiology 4, 301-305.

SMith, H. W. \& LingGoOd, M. A. (1972). Further observation on Escherichia coli enterotoxins with particular regard to those produced by atypical piglet strains and by calf and lamb strains: the transmissible nature of these enterotoxins and $K$ antigen possessed by calf and lamb strains. Journal of Medical Microbiology 5, 243-249.

SMYTH, C. J. (1982). Two mannose-resistant haemagglutinins on enterotoxigenic Escherichia coli of serotype $06: \mathrm{K} 15: \mathrm{H} 16$ or $\mathrm{H}^{-}$isolated from travellers' and infantile diarrhoea. Journal of General Microbiology 128, 2081-2096.

So, M., Boyer, H. W., Betlach, M. \& Falkow, S. (1976). Molecular cloning of an Escherichia coli plasmid determinant that encodes for the production of heat-stable enterotoxin. Journal of Bacteriology 128, 463-472.

So, M., Hefrron, F. \& McCarty, B. J. (1979). The $E$. coli gene encoding heat-stable toxin is a bacterial transposon flanked by inverted repeats of IS 1 . Nature, London 277, 453-456.

STAVRIC, S. \& JEFFreY, D. (1977). A modified bioassay for heat-stable Escherichia coli enterotoxin. Canadian Journal of Microbiology 23, 331-336. 
STIRM, S., ØRSKov, F., ØRSKOV, I. \& BIRCH-ANDERSON, A. (1967). Episome-carried surface antigen K88 of E. coli. III. Morphology. Journal of Bacteriology 93, 740-748.

To, S. C. M. (1984). F41 antigen among porcine enterotoxigenic Escherichia coli strains lacking K88, $\mathrm{K} 99$ and 987P pili. Infection and Immunity 43, 549554.
Van Embden, J. D. A., De Graaf, F. K., Shouls, L. M. \& TEPPEMA, J. S. (1980). Cloning and expression of a deoxyribonucleic acid fragment that encodes for the adhesive antigen K99. Infection and Immunity 29, 1125-1133. 